\title{
Transcultural adaptation and validation of familial satisfaction in the intensive care unit in Korea: preliminary study
}

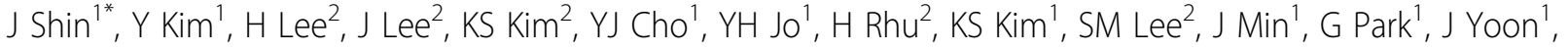 \\ SI Park', YJ Lee ${ }^{1}$
}

From ESICM LIVES 2015

Berlin, Germany. 3-7 October 2015

\section{Introduction}

Lately, in North America, questionnaires have been developed and validated, which were to assess family needs and satisfaction with care in the intensive care unit. One of the most widely used one is FS-ICU-24 survey.

\section{Objectives}

The purpose of this study is to prove the Korean version of FS-ICU-24 survey.

\section{Methods}

The study was performed in the medical, surgical, and emergency ICU of Seoul National University Bundang Hospital and Seoul National University Hospital. Relatives of all patients with a length of stay of 48 hours or longer were eligible for the study. And the validation included feasibility, construct validity, internal consistency, reliability and sensitivity. The survey consisted of 24 items and two categories: (i) satisfaction with care (14 items) and (ii) satisfaction with decision making (10 items).

\section{Results}

The translated form was distributed to 81 family members. The response rate was $61.7 \%$ and $97.9 \%$ of questions in returned forms were answered. Compared with a Visual Analogue Scale, the construct validity was good for the total survey satisfaction (Spearman $\mathrm{p}=0.795$ ). A Cronbach a coefficient for satisfaction with care subscale was 0.953 ; for satisfaction with decision making subscale was 0.886 . The total FS-ICU-24 survey mean score was

${ }^{1}$ Seoul National University Bundang Hospital, Seongnam, Korea, Republic of Full list of author information is available at the end of the article
$78.48 \pm 15.56$. In this study, the responders were most satisfied with having adequate time to have their concerns addressed and questions answered (89.8 \pm 30.58$)$ and least satisfied with the atmosphere of the ICU waiting room (41.46 \pm 36.91$)$.

\section{Conclusions}

A cross-cultural adaptation of FS-ICU-24 into Korean version can be validated enough and will be acquired reliability.

\section{Authors' details \\ ${ }^{1}$ Seoul National University Bundang Hospital, Seongnam, Korea, Republic of.}

${ }^{2}$ Seoul National University Hospital, Seoul, Korea, Republic of.

Published: 1 October 2015

doi:10.1186/2197-425X-3-S1-A654

Cite this article as: Shin et al:: Transcultural adaptation and validation of familial satisfaction in the intensive care unit in Korea: preliminary study. Intensive Care Medicine Experimental 2015 3(Suppl 1):A654.

Submit your manuscript to a SpringerOpen ${ }^{\odot}$ journal and benefit from:

- Convenient online submission

- Rigorous peer review

- Immediate publication on acceptance

- Open access: articles freely available online

- High visibility within the field

- Retaining the copyright to your article

Submit your next manuscript at $>$ springeropen.com

\section{SpringerOpen $^{\circ}$}

C 2015 Shin et al.; This is an Open Access article distributed under the terms of the Creative Commons Attribution License (http:// creativecommons.org/licenses/by/4.0), which permits unrestricted use, distribution, and reproduction in any medium, provided the original work is properly cited. 